\title{
Mayamaea vietnamica sp. nov.: a new, terrestrial diatom (Bacillariophyceae) species from Vietnam
}

\author{
Elena Kezlya ${ }^{1}$, Anton Glushchenko ${ }^{1}$, John Patrick Kociolek ${ }^{2,3}$, Yevhen Maltsev ${ }^{1}$, \\ Nikita Martynenko ${ }^{1}$, Sergei Genkal ${ }^{4}$ and Maxim Kulikovskiy ${ }^{1, *}$ \\ ${ }^{1}$ K.A. Timiryazev Institute of Plant Physiology RAS, IPP RAS, 35 Botanicheskaya St., Moscow, 127276, Russia \\ ${ }^{2}$ Museum of Natural History, Henderson Building, 15th and Broadway, Boulder, CO 80309, USA \\ ${ }^{3}$ Department of Ecology and Evolutionary Biology, University of Colorado, Boulder, CO 80309,USA \\ ${ }^{4}$ Papanin Institute for Biology of Inland Waters RAS, IBIW RAS, Borok, Yaroslavl Region, 152742, Russia
}

A new diatom species, Mayamaea vietnamica sp. nov., is described from Cát Tiên National Park in Vietnam. This species was discovered and described from soil samples. Algae from soil ecosystems in Vietnam are almost unknown. The new species is described on the basis of an integrated approach with molecular and morphological data, and comparison with similar species. In terms of molecular data, 18S rDNA (including V4 domain), and partial $r b c \mathrm{~L}$ plastid genes show M. vietnamica sp. nov. is most closely related to M. terrestris N. Abarca and R. Jahn, and together they form a monophyletic group relative to other members of the genus. M. vietnamica sp. nov. differs from other species in the genus by the number of striae and areolae in $10 \mu \mathrm{m}$, number of areolae per stria, as well as shape and presence or absence of axial and central areas.

Key Words: Bacillariophyceae; diatoms; Mayamaea vietnamica; molecular; morphology; Vietnam

\section{INTRODUCTION}

The genus Mayamaea was proposed by Lange-Bertalot (1997). Initially, 13 taxa formerly attributed to Navicula sensu lato were included in the genus (Lange-Bertalot 1997). Mayamaea includes small-celled species that are elliptical in shape. The main characteristic of the genus is the arrangement of the pore occlusions, which are hymenes that cover the areolae from the outside, as well as the presence of a pronounced sternum found in the vast majority of species. The location of the hymenes is an important characteristic that differentiates Mayamaea from the genera Eolimna Lange-Bertalot and W. Schiller and Sellaphora Mereschkowsky, otherwise these genera have much in common including the structure of the raphe, central pores and distal raphe ends (Barragán et al. 2017). Therefore, accurate identification by morphological characteristics is possible only when studying the material using a scanning electron microscope. Currently, the genus has about 30 taxa (Guiry and Guiry 2020, Kociolek et al. 2020). Species of the genus Mayamaea are distributed worldwide, though most species are known from Europe (Barragán et al. 2017). The species Mayamaea agrestis (Hustedt) Lange-Bertalot (basionym: Navicula agrestis Hustedt) was described from Southeast Asia (Indonesia) (Hustedt in Schmidt 1936, Hustedt 1937).

Species of Mayamaea prefer humid terrestrial habitats, as well as freshwater ecosystems (oligotrophic and
(9) This is an Open Access article distributed under the terms of the Creative Commons Attribution Non-Commercial License (http://creativecommons.org/licenses/by-nc/3.0/) which permits unrestricted non-commercial use, distribution, and reproduction in any medium, provided the original work is properly cited.
Received July 2, 2020, Accepted November 23, 2020

* Corresponding Author

E-mail: max-kulikovsky@yandex.ru

Tel: +7-916-456-43-70, Fax: +7-499-678-54-20 
mesotrophic), including in the littoral zone of these environments (Lange-Bertalot 1997, Kulikovskiy 2006, Kulikovskiy et al. 2016). In discussing the ecology of the species, Barragán et al. (2017) suggest that soil habitats are typical for M. lacunolaciniata (Lange-Bertalot and Bonik) Lange-Bertalot, $M$. muraliformis Lange-Bertalot, $M$. terrestris $\mathrm{N}$. Abarca and $\mathrm{R}$. Jahn, and M. petersenii Barragán, Ector and C. E. Wetzel. However, some other species have also been found in the soil. For example, M. atomus (Kutzing) Lange-Bertalot was found in the soil of paddy fields in Central Japan (Ohtsuka and Fujita 2001). A large number of diatom species (147 taxa) were identified from cultivated soils in Podkarpacie Province, Poland (Noga et al. 2014), and the most numerous was M. atomus and 5 other species. Others species of Mayamaea were found as well, including $M$. agrestis (Hustedt) Lange-Bertalot, $M$. excelsa (Krasske) Lange-Bertalot, M. permitis (Hustedt) Bruder \& Medlin, $M$. cf. recondita (Hustedt) Lange-Bertalot, Mayamaea sp 2. Foets et al. (2020) found M. atomus (Kützing) Lange-Bertalot as a dominant in the soil of the Attert River basin (Luxembourg). The authors revealed that M. agrestis (Hustedt) Lange-Bertalot was typically on agricultural grasslands, M. permitis (Hustedt) Bruder \& Medlin was one of the most abundant species in the territory, and M. fossalis (Krasske) was found in undisturbed grassland soils.

Molecular genetic data on Mayamaea species are scarce. A study of two strains of $M$. atomus (Kützing) Lange-Bertalot and one strain of M. atomus var. permitis (Hustedt) Lange-Bertalot showed that they form a monophyletic group, separate from but related to representatives of Pinnularia Ehrenberg and Caloneis Cleve (Bruder and Medlin 2008). Further, the results of studying the molecular markers $18 \mathrm{~S} \mathrm{~V} 4$ and $r b c \mathrm{~L}$ for strains of M. atomus, M. permitis (Hustedt) Bruder and Medlin, $M$. fossalis (Krasske) Lange-Bertalot, and M. terrestris were summarized by Zimmermann et al. (2014). The authors included their own sequences and all available data from the INSDC database. It was shown that all strains identified as M. terrestris and M. permitis form an independent clade between Navicula Bory and Caloneis. Currently, in the NCBI database 59 sequences for seven taxa have been deposited: $M$. atomus, $M$. permitis, $M$. fossalis, $M$. terrestris, Mayamaea sp. KAS1111, Mayamaea sp. DMMEX020, and Mayamaea sp. DM-MEX019.

We also note that the only mention of soil diatoms from Southeast Asia (Indonesia) refers to the work of Kolkwitz and Krieger (1936), where the authors used one soil sample ("Humus unter Bäumen", Humus under the trees, 2,700 m, pH = 4.3) from Mount Pangrango. The fol- lowing species were identified by the authors: Eunotia pectinalis (Kützing) Rabenhorst, E. praerupta var. thermalis Hustedt, Melosira dickiei (Thwaites) Kützing, Navicula contenta Grunow in Van Heurck and Pinnularia lata var. thuringiaca (Rabenhorst) Ant. Mayer.

Previously, we described species of the genera $\mathrm{Au}$ lacoseira Thwaites, Eunotia Ehrenberg, Gomphonema Ehrenberg and Luticola D. G. Mann (Glushchenko et al. 2016, 2017a, 2017b, 2018) from freshwater reservoirs of Cát Tiên National Park (Vietnam). However, the present report is the first study on the soil algae in this area.

This work provides a morphological description and molecular data on the $18 \mathrm{~S} \mathrm{~V} 4$ and $r b c \mathrm{~L}$ genetic markers for a new species from the genus Mayamaea isolated into a monoclonal culture from a soil sample from the territory of Cát Tiên National Park. The work is the first, and part of a larger project, on the study of soil algae in Vietnam. To date, 57 soil samples from the national park have been studied and 565 algae strains have been isolated.

\section{MATERIALS AND METHODS}

\section{Study area}

Cát Tiên National Park is located in southern Vietnam, $150 \mathrm{~km}$ northeast of Ho Chi Minh City (Fig. 1). The park was established in 1978 and consists of three parts with a total area of 73,878 ha (Blanc et al. 2001). The region belongs to the bioclimatic type of monsoon tropical climate with summer rains. Relative humidity, as a rule, always exceeds $70 \%$, with an average annual temperature of about $26^{\circ} \mathrm{C}$. From December to March there is almost no rainfall. Southwest monsoons last eight months, from April to November, when most of the precipitation is observed. The wet season peaks in August-September. At this time of the year, up to $400-450 \mathrm{~mm}$ of precipitation falls per month, which leads to flooding of a significant part of the park. The main part of the territory is occupied by forests, which are of the monsoon, semi-deciduous type. These forests are characterized by high biological diversity and high productivity, second only to moist tropical forests in this respect (Blanc et al. 2001).

\section{Sampling}

The sample used in the present report was collected from Vietnam by E. S. Gusev, Jun 9, 2018, and designated No. 06460, from the Cát Tiên National Park, Đồng Nai Province $\left(11^{\circ} 28.820^{\prime} \mathrm{N}, 107^{\circ} 22.836^{\prime} \mathrm{E}\right)$. It was comprised 

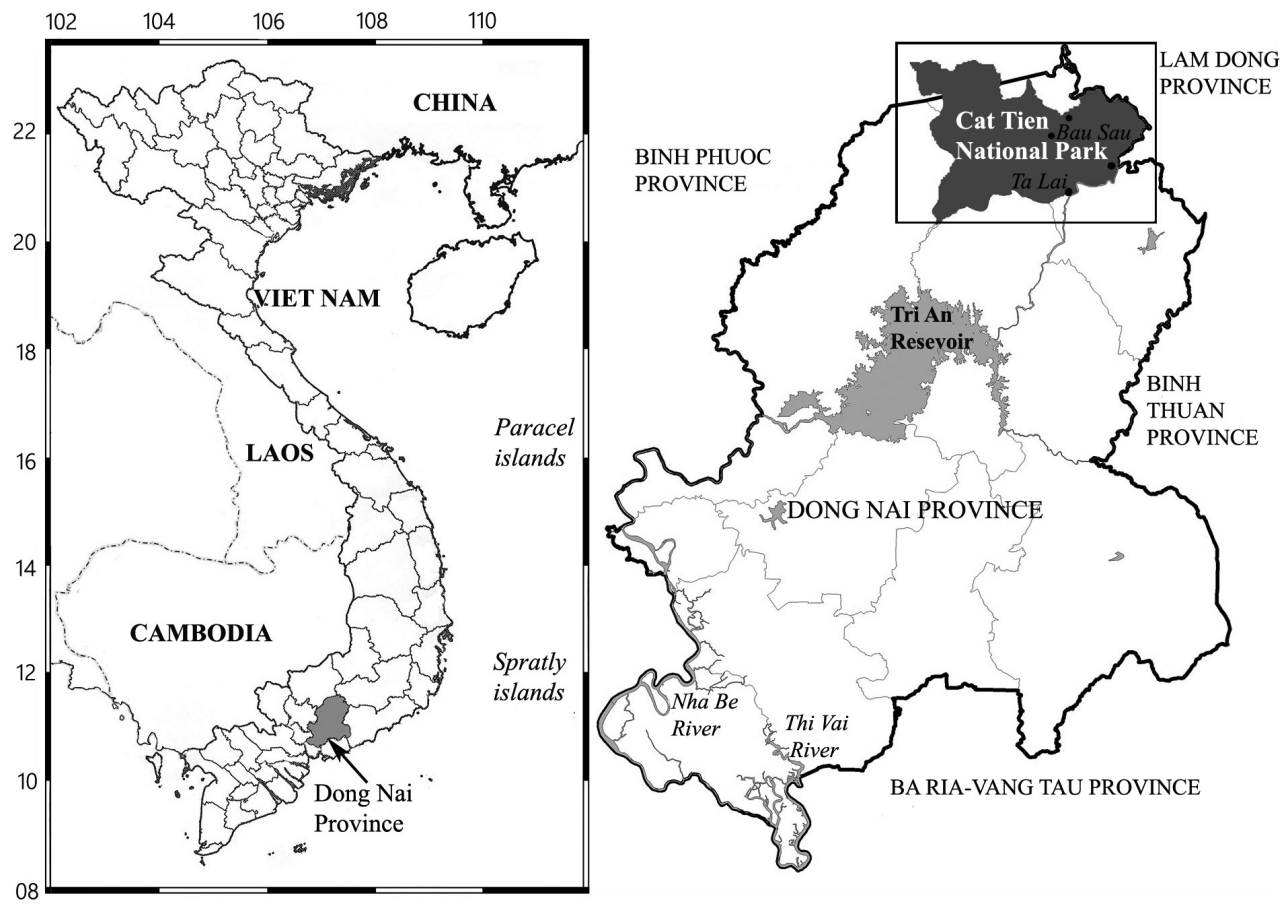

Fig. 1. Geographical position of the studied area.

of wet soil, which had a pH of 6.5. Samples in general were taken as follows: first, the surface of the test site was examined in order to detect macrogrowth of algae, then a combined sample was taken from an area of 10-30 $\mathrm{m}^{2}$ using the metal scoop or shovel. The composite sample consists of 5-10 individual samples. For an individual sample, the topsoil was removed from an area of 5 to 20 $\mathrm{cm}^{2}$. After selection, the instruments were cleaned and sterilized with ethanol. Samples were placed in plastic zip bags, labeled. Immediately after the selection, the absolute humidity was determined in the laboratory room by the "hot drying" method (Vadjunina and Korchagina 1986), then air dried and packaged.

\section{Measurement of $\mathrm{pH}$}

To measure $\mathrm{pH}$, we weighed $30 \mathrm{~g}$ of soil to which 150 $\mathrm{mL}$ of distilled water was added. The suspension was poured into a clean glass and measurements were made using the Hanna Combo device (HI 98129; Hanna Instruments, Inc., Woonsocket, RI, USA) (Arinushkina 1970).

\section{Culturing}

Isolation and cultivation of algae strains was carried out at the Institute of Plant Physiology Russian Academy of Sciences. A subsample of each collection was added to WC liquid medium (Guillard and Lorenzen 1972). Monoclonal strains were established by micropipetting single cells under an inverted microscope. Non-axenic unialgal cultures were maintained in WC liquid medium at $22-25^{\circ} \mathrm{C}$ in a growth chamber with a $12: 12 \mathrm{~h}$ light : dark photoperiod.

\section{Preparation of slides and microscope investiga- tion}

The culture was treated with $10 \%$ hydrochloric acid to remove carbonates and washed several times with deionized water for $12 \mathrm{~h}$. Afterwards, the sample was boiled in concentrated hydrogen peroxide $(\approx 37 \%)$ to remove organic matter. It was washed again with deionized water four times at $12 \mathrm{~h}$ intervals. After decanting and filling with deionized water up to $100 \mathrm{~mL}$, the suspension was pipetted onto coverslips and left to dry at room temperature. Permanent diatom preparations were mounted in Naphrax. Light microscopic (LM) observations were performed with a Zeiss Axio Scope Al microscope (Carl Zeiss Microscopy GmbH, Gottingen, Germany) equipped with an oil immersion objective $(\times 100$, n.a. 1.4 , differential interference contrast) and Axiocam ERc 5s camera (Carl Zeiss Microscopy $\mathrm{GmbH}$ ). Valve ultrastructure was exam- 
ined using a scanning electron microscope JSM-6510LV (IBIW; Institute for Biology of Inland Waters RAS, Borok, Russia). For scanning electron microscopy (SEM), part of the suspensions was fixed on aluminum stubs after airdrying. The stubs were sputter-coated with $50 \mathrm{~nm}$ of $\mathrm{Au}$ using an Eiko IB 3 machine (Eiko Engineering Co. Ltd., Tokyo, Japan).

The suspension and slides are deposited in the collection of Maxim Kulikovskiy at the Herbarium of the Institute of Plant Physiology Russian Academy of Sciences, Moscow, Russia.

\section{Extraction of DNA and amplification}

Total DNA of monoclonal cultures was extracted using InstaGene Matrix (Bio-Rad, Hercules, CA, USA) according to the manufacturer's protocol. Fragments of $18 \mathrm{~S}$ rDNA (323 bp, including V4 domain) and partial $r b c \mathrm{~L}$ plastid genes (978 bp) were amplified using primers D512for and D978rev from Zimmerman et al. (2011) for 18S rDNA fragments and $r b c \mathrm{~L} 40+$ from Ruck and Theriot (2011) and $r b c \mathrm{~L} 1255$ - from Alverson et al. (2007) for $r b c \mathrm{~L}$ fragments.

Amplifications of the 18S rDNA fragments and partial $r b c \mathrm{~L}$ gene fragment were carried out using the premade mix ScreenMix (Evrogen, Moscow, Russia) for the polymerase chain reaction (PCR). The conditions of amplification for 18S rDNA fragments were: an initial denaturation of $5 \mathrm{~min}$ at $95^{\circ} \mathrm{C}$, followed by 35 cycles at $94^{\circ} \mathrm{C}$ for denaturation $(30 \mathrm{~s}), 52^{\circ} \mathrm{C}$ for annealing $(30 \mathrm{~s})$ and $72^{\circ} \mathrm{C}$ for extension (50 s), and a final extension of $10 \mathrm{~min}$ at $72^{\circ} \mathrm{C}$. The conditions of amplification for partial $r b c \mathrm{~L}$ were: an initial denaturation of $5 \mathrm{~min}$ at $95^{\circ} \mathrm{C}$, followed by 45 cycles at $94^{\circ} \mathrm{C}$ for denaturation $(30 \mathrm{~s}), 59^{\circ} \mathrm{C}$ for annealing (30 s) and $72^{\circ} \mathrm{C}$ for extension (80 s), and a final extension of $10 \mathrm{~min}$ at $72^{\circ} \mathrm{C}$.

The resulting amplicons were visualized by horizontal agarose gel electrophoresis (1.5\%), colored with SYBR Safe (Life Technologies, Carlsbad, CA, USA). Purification of DNA fragments was performed with the ExoSAP-IT kit (Affimetrix, Santa Clara, CA, USA) according to the manufacturer's protocol. 18S rDNA fragments and partial $r b c \mathrm{~L}$ gene were decoded from two sides using forward and reverse PCR primers and the Big Dye system followed by electrophoresis using a Genetic Analyzer 3500 sequencer (Applied Biosystems, Foster City, CA, USA).

Editing and assembling of the consensus sequences were carried out by comparing the direct and reverse chromatograms using the Ridom TraceEdit program ver. 1.1.0 (Ridom GmbH, Würzburg, Germany) and Mega7 (Kumar et al. 2016). Newly determined sequences and
DNA fragments of 106 other diatoms, which were downloaded from GenBank (taxa and accession numbers are given in the tree) (Fig. 2), were included in the alignments. Four centric diatom species were chosen as the outgroups.

The nucleotide sequences of the $18 \mathrm{~S}$ rDNA and $r b c \mathrm{~L}$ genes were aligned separately using the Mafft v7 software and the E-INS-i model (Katoh and Toh 2010). For the protein-coding sequences of the $r b c \mathrm{~L}$ gene, we checked that the beginning of the aligned matrix corresponded to the first position of the codon (triplet). The resulting alignments had lengths of $402(18 \mathrm{~S} \mathrm{rDNA})$ and $978(r b c \mathrm{~L})$ characters.

The data set was analyzed using Bayesian inference (BI) method implemented in Beast ver. 1.10.1. (Drummond and Rambaut 2007) to construct the phylogeny. For each of the alignment partitions, the most appropriate substitution model was estimated using the Bayesian information criterion (BIC) as implemented in jModelTest 2.1.10 (Darriba et al. 2012). This BIC-based model selection procedure selected the following models, shape parameter $\alpha$ and a proportion of invariable sites (pinvar): $\operatorname{TrN}+\mathrm{I}+\mathrm{G}, \alpha=0.4410$ and pinvar $=0.3730$ for $18 \mathrm{~S}$ rDNA; $\mathrm{TIM} 1+\mathrm{I}+\mathrm{G}, \alpha=0.5030$ and pinvar $=0.5960$ for the first codon position of the $r b c \mathrm{~L}$ gene; TIMlef $+\mathrm{I}+\mathrm{G}, \alpha=0.2490$ and pinvar $=0.6820$ for the second codon position of the $r b c \mathrm{~L}$ gene; $\mathrm{TVM}+\mathrm{I}+\mathrm{G}, \alpha=0.7500$ and pinvar $=0.1150$ for the third codon position of the $r b c \mathrm{~L}$ gene. We used the GTR model of nucleotide substitution instead of TIM1, TIMlef and TVM, given that they were the best matching model available for BI method. A Yule process tree prior was used as a speciation model. The analysis ran for 10 million generations with chain sampling every 1,000 generations. The parameters-estimated convergence, effective sample size and burn-in period were checked using the software Tracer ver. 1.7.1. (Drummond and Rambaut 2007). The initial $25 \%$ of the trees were removed, the rest retained to reconstruct a final phylogeny. The phylogenetic tree and posterior probabilities of its branching were obtained on the basis of the remaining trees, having stable estimates of the parameter models of nucleotide substitutions and likelihood. Maximum likelihood (ML) analysis was performed using the program RAxML (Stamatakis et al. 2008). The nonparametric bootstrap analysis with 1,000 replicas was used. The statistical support values were visualized in FigTree ver. 1.4.4 (http:// tree.bio.ed.ac.uk/software/figtree/) and Adobe Photoshop CC 19.0 (Adobe Systems, San José, CA, USA). 


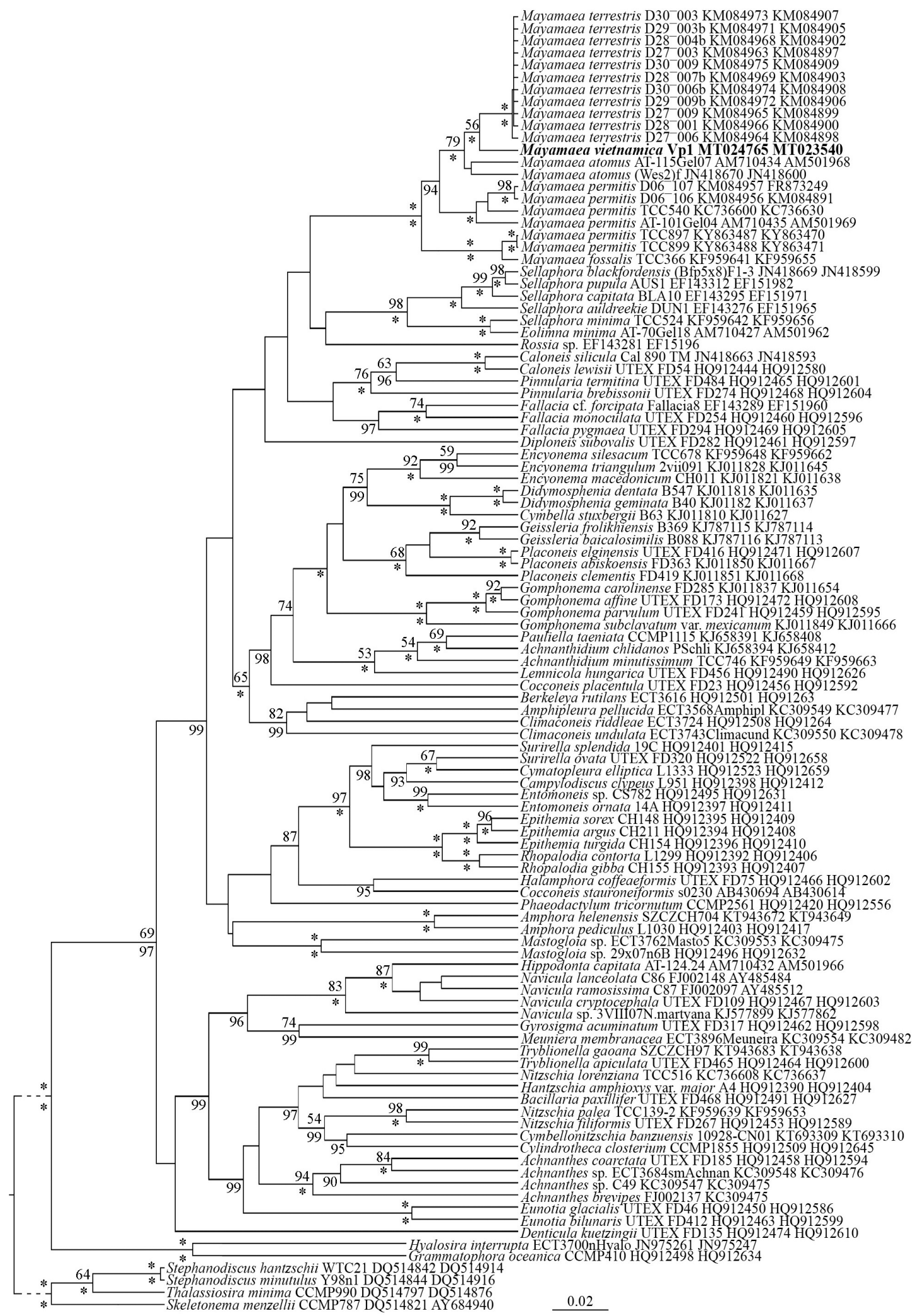

Fig. 2. Bayesian tree of Mayamaea vietnamica sp. nov. (indicated in bold) constructed from a concatenated alignment of 107 partial $r b c L$ and partial $18 \mathrm{~S}$ rDNA sequences of 1,380 characters. Values above the horizontal lines are bootstrap support from RAxML analyses $(<50$ are not shown); values below the horizontal lines are Bayesian posterior probabilities ( $<90$ are not shown). All sequences have strain numbers (if available) and GenBank numbers. Species from the centric diatoms were used as an outgroup. Asterisks represent 100\% statistical support. 


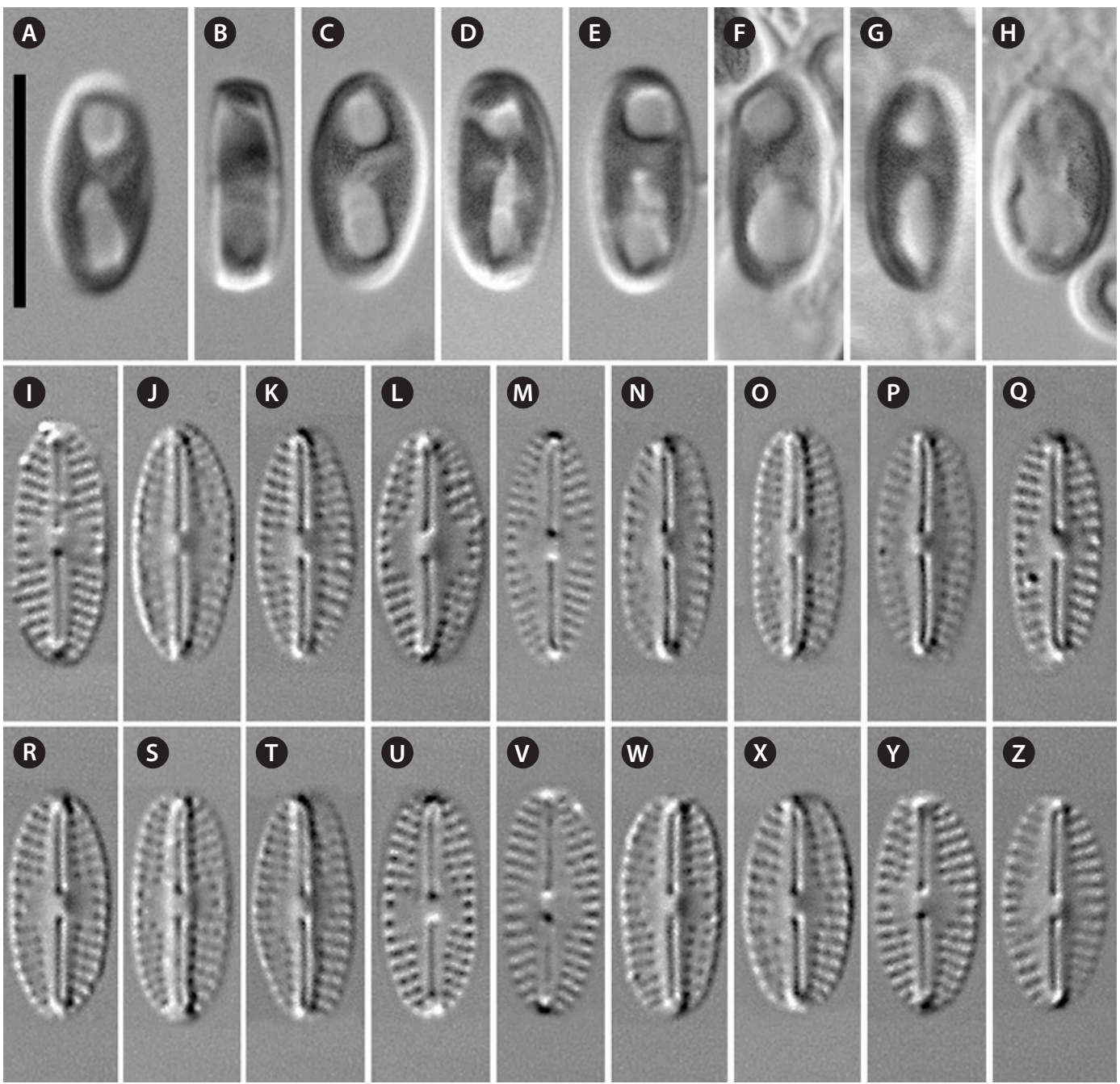

Fig. 3. Mayamaea vietnamica Glushchenko, Kezlya, Kulikovskiy \& Kociolek sp. nov. Strain VP 1, slide No. 06460. Light microscopy, differential interference contrast. (A \& C-Z) Valves face. (A-H) Live cells with chloroplast structure. (B) Cell in girdle view. (I-Z) Size diminution series. (K) Holotype. Scale bar represents: $10 \mu \mathrm{m}$.

\section{RESULTS}

\section{Mayamaea vietnamica Glushchenko, Kezlya, Kulikovskiy \& Kociolek sp. nov. (Figs 3-5)}

Holotype. Collection of Maxim Kulikovskiy at the Herbarium of the Institute of Plant Physiology Russian Academy of Science, Moscow, Russia, holotype here designated, slide No. $06460=$ Fig. 3K. Strain VP 1 isolated from forest soil.

Type locality. Vietnam, Cát Tiên National Park, Đồng Nai Province, forest soil $\left(11^{\circ} 28.820^{\prime} \mathrm{N}, 107^{\circ} 22.836^{\prime} \mathrm{E}\right)$. Leg. E. S. Gusev, Jun 9, 2018.

Etymology. The specific epithet refers to the name of the country where this species was observed.
Distribution. As yet known only from the type locality.

Description. LM (Fig. 3A-Z): Cells solitary, rectangular in girdle view (Fig. 3B). One H-shaped plastid, with one arm lying against each side of the girdle, connected by a narrow central isthmus (Fig. 3A \& C-H). Valves small, from almost linear to elliptical and oval $(n=29)$ with pronounced sternum and broadly rounded ends. Length 9.1-10.5 $\mu \mathrm{m}$, breadth 3.9-4.8 $\mu \mathrm{m}$. Raphe narrow, linear. Central area more or less expressed, rounded to asymmetrical, rarely transversally elongated, and bordered on each margin by 3 shortened striae and / or 3 isolated areolae. Axial area tapers from the central area, becoming narrower towards the ends. The striae are radiate throughout the valve, 19-22 in $10 \mu \mathrm{m}$. Areolae coarse, clearly visible in LM. 

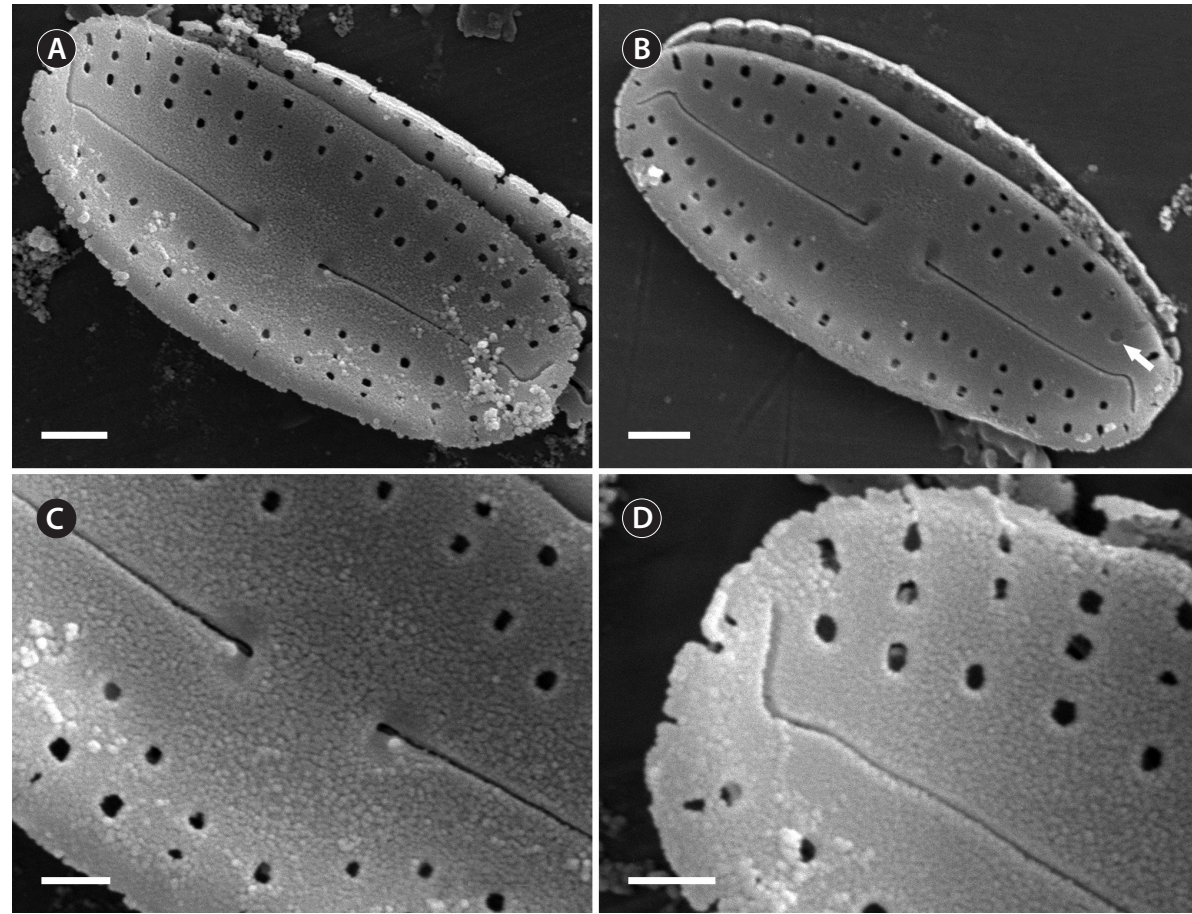

Fig. 4. Mayamaea vietnamica Glushchenko, Kezlya, Kulikovskiy \& Kociolek sp. nov. Strain VP 1, slide No. 06460. Scanning electron microscopy, external views. (A \& B) Whole valve. Areola occluded by hymen (arrow). (C) Central area. (D) Valve end. Scale bars represent: A \& B, $1 \mu \mathrm{m} ; C$ \& D, $0.5 \mu \mathrm{m}$.

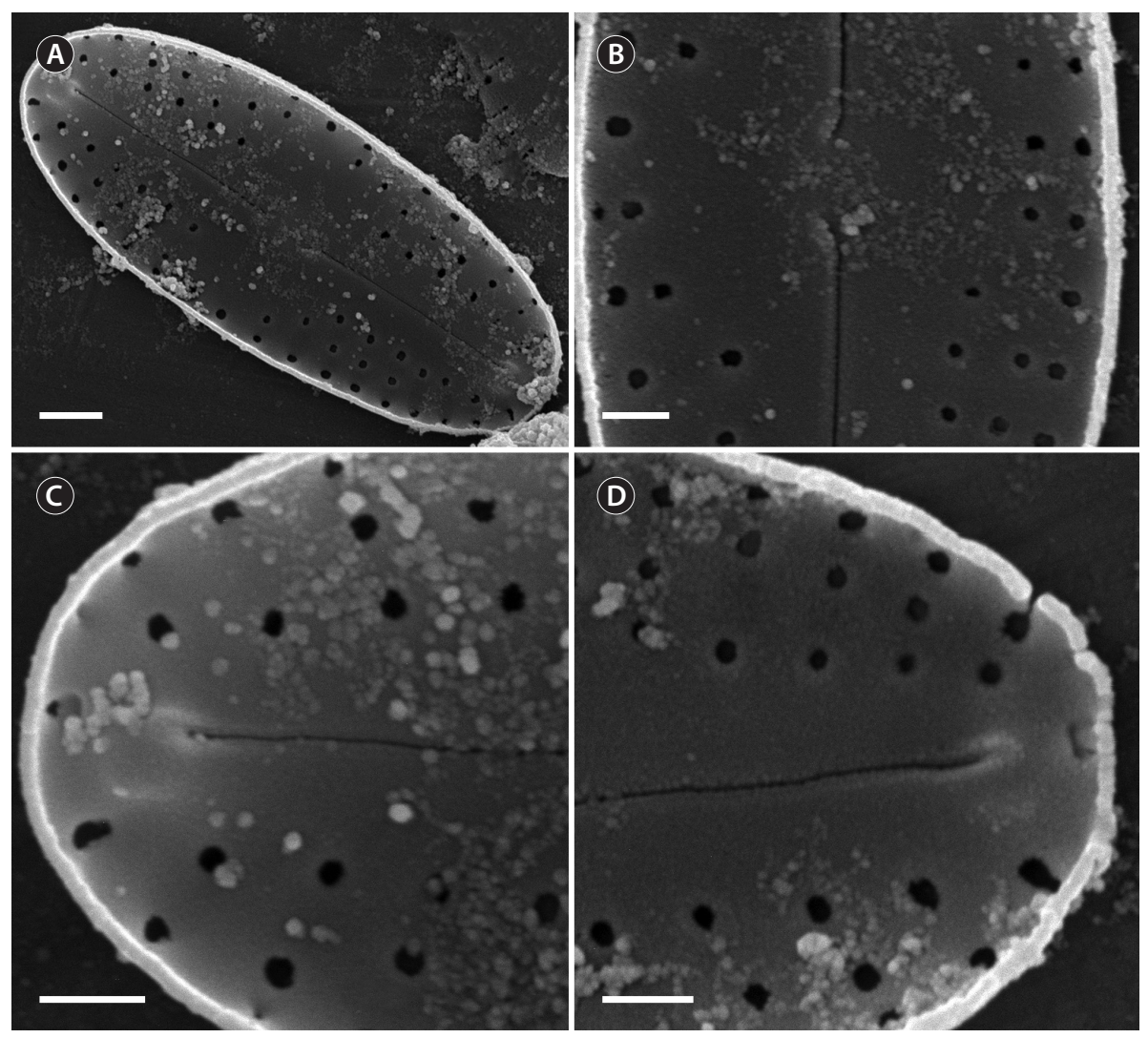

Fig. 5. Mayamaea vietnamica Glushchenko, Kezlya, Kulikovskiy \& Kociolek sp. nov. Strain VP 1, slide No. 06460. Scanning electron microscopy, internal views. (A) Whole valve. (B) Central area. (C \& D) Valves ends. Scale bars represent: A, $1 \mu \mathrm{m} ; \mathrm{B}-\mathrm{D}, 0.5 \mu \mathrm{m}$. 
SEM, external views (Fig. 4A-D): Raphe narrow, linear (Fig. 4A \& B). Proximal raphe ends straight, dropshaped (Fig. 4C). Distal raphe fissures bending strongly to the same side of valve mantle (Fig. 4A, B \& D). Striae composed in 1-3 round areolae, not extending to valve margin (Fig. 4A-D). Areolae round, covered by individual hymenes (example, Fig. 4B, white arrow).

SEM, internal views (Fig. 5A-D): Raphe narrow, linear (Fig. 4A). Proximal valve ends slightly deflected to one side (Fig. 4B). Distal raphe ends terminating in small helictoglossae (Fig. 4C \& D).

Molecular investigation (Fig. 2). Phylogenetic analysis of molecular sequence data shows that our new taxon, $M$. vietnamica sp. nov., is part of a branch with other species of Mayamaea (ML, 56; BI, 100). The branch with Mayamaea species is well-supported (ML, 100; BI, 100) and independent from other branches. Closely related to the monophyletic group of Mayamaea species is a branch with strains of species from the genera Sellaphora and Eolimna. The branch containing these genera also has high statistical support (ML, 98; BI, 100). Six strains of M. permitis are divided in two branches in our molecular tree. This suggests the presence of at least two cryptic species from specimens whose morphology suggest they could be assigned to the taxon $M$. permitis sensu lato. $M$. fossalis is close to two strains of M. permitis, however a difference between these species is supported by high statistical support (ML, 100; BI, 100). This result shows that these two species are independent taxa based on this current molecular investigation.

\section{DISCUSSION}

Mayamaea vietnamica sp. nov. possesses all of the typical characters of the genus Mayamaea (Lange-Bertalot 1997). These features include hymenes that covers the areolae from the outside, uniseriate striae, large areolae, small size, as well as the presence of a pronounced sternum. Our new species is morphologically similar to some known species from the genus Mayamaea, but it differs from them by both quantitative and qualitative features (see Table 1). The results of our molecular investigation show the new species is part of an independent branch the includes three taxa. M. vietnamica sp. nov. is more closely related to $M$. terrestris than either is to M. atomus. Additionally, M. permitis and M. fossalis were included in the molecular investigation. The lineage of Mayamaea taxa is part of a broader monophyletic group that includes species of the genera Sellaphora, Eolimna and
Rossia M. Voigt (see Fig. 2). However, the results of our molecular investigation show that there is high statistical support for recognizing Mayamaea as a genus distinct from these other genera (see above).

In Table 1, we compare species of Mayamaea that are morphologically similar to our new species described herein. The type species of Mayamaea is M. atomus and this species is similar in valve shape to M. vietnamica sp. nov. However, M. vietnamica sp. nov. differs from M. atomus in general by having a lower density of areolae (20-30 at $10 \mu \mathrm{m}$ in M. vietnamica sp. nov. vs. $40-50$ at $10 \mu \mathrm{m}$ in $M$. atomus), as well as a lower number of areolae in the striae (1-3 in M. vietnamica sp. nov. vs. 1-8 in M. atomus). In addition, the axial area of M. vietnamica sp. nov. is much wider than that of M. atomus, whose axial area is narrow, corresponds to the sternum, while in M. vietnamica sp. nov. the axial area is markedly expressed, tapering from the central area becoming narrower towards the ends of the valves. The central area of M. atomus is small or absent, which is not observed in M. vietnamica sp. nov., the central area of which is always noticeably pronounced.

The species Mayamaea crassistriata Lange-Bertalot, Cavacini, Tagliaventi and Alfinito (Lange-Bertalot et al. 2003) is similar to M. vietnamica sp. nov. and both taxa have axial areas that broaden into to the central area. However, a central area is absent in M. crassistriata, while in M. vietnamica sp. nov. it is well expressed. In addition, the axial area is much wider in M. vietnamica sp. nov. $M$. crassistriata is characterized by a higher density of areolae (ca. 40 in $10 \mu \mathrm{m}$ vs. 20-30 in $10 \mu \mathrm{m}$ in M. vietnamica sp. nov.). The number of areolae in striae is also higher in M. crassistriata (which has 2-6 vs. 1-3 in M. vietnamica sp. nov.).

The morphologically most similar species to M. vietnamica sp. nov. is Mayamaea fossalis (Krasske 1929, p. 354, fig. 10; Lange-Bertalot et al. 1996, p. 109, 110, Pl. 19, figs 14 \& 15; Lange-Bertalot 2001, p. 138, Pl. 104, figs 2530). In general, the valves of $M$. vietnamica sp. nov. have less convex valve margins. The axial area of $M$. fossalis is clear, narrow-lanceolate, more rarely linear, in the middle expanded roundish-lanceolate, differentiating a central area due to some shortened striae. The central area in $M$. vietnamica sp. nov., is well defined and transversely widened; it is surrounded by shortened striae. However, the striae in M. fossalis appear more strongly radiate than in M. vietnamica sp. nov. M. fossalis is the only species that has coarse areolae. Mayamaea fossalis and M. vietnamica sp. nov. have similar striae densities (16-21 in $10 \mu \mathrm{m}$ in $M$. fossalis vs. 19-22 in $10 \mu \mathrm{m}$ in M. vietnamica sp. nov.) and areolae (ca. 22 in $10 \mu \mathrm{m}$ in M. fossalis vs. 20-30 in $10 \mu \mathrm{m}$ in 
M. vietnamica sp. nov.) (Lange-Bertalot 2001). However, $M$. fossalis has a greater number of areolae in the stria (up to 3 , 4, or 5) (Reichardt 2018, p. 170, Pl. 125, LM figs 42-51, Pl. 126, SEM figs 9 \& 10), while in M. vietnamica sp. nov. there are no more than 2 or 3 areolae per stria. One SEM of the valve exterior of $M$. fossalis showed only 2 or 3 areolae per stria and striae slightly radiate, was published by Reichardt (2018, Pl. 126, fig. 8, with the specimen coming from a small stream in the war cemetery on Nagelberg Bächlein in der Kriegsgräberstätte am Nagelberg, Germany), and this specimen might be $M$. vietnamica sp. nov. Another SEM micrograph of an external valve, named as “Mayamaea cf. fossalis" by Barragán et al. (2017, SEM fig. 40, from Craste de Louley River at Lacanau, France), also probably corresponds to $M$. vietnamica sp. nov. Despite the morphological similarity, molecular genetic data do not show a close relationship between $M$. vietnamica sp. nov. and M. fossalis (Fig. 2).

Mayamaea recondita (Hustedt) Lange-Bertalot is morphologically similar to $M$. vietnamica sp. nov. in valve shape. There is no central area in $M$. recondita, while in $M$. vietnamica sp. nov. the central area is well defined. Moreover, the axial area of $M$. recondita is generally narrower than that of $M$. vietnamica sp. nov. Striae of $M$. recondita are biseriate, while in our species they are uniseriate, the density of areolae is highest among representatives of the genus (70-80 in $10 \mu \mathrm{m})$, in comparison with M. vietnamica sp. nov. (20-30 in $10 \mu \mathrm{m})$. Also, the number of areolae

Table 1. Morphological comparison of Mayamaea species on the basis of published data and current report

\begin{tabular}{|c|c|c|c|c|c|c|}
\hline & M. vietnamica sp. nov. & M. atomus ${ }^{\mathrm{a}}$ & M. crassistriata ${ }^{\mathrm{a}}$ & M. fossalis ${ }^{\mathrm{a}}$ & M. recondite ${ }^{\mathrm{a}}$ & M. terrestris ${ }^{\mathrm{a}}$ \\
\hline Outline & $\begin{array}{l}\text { Almost linear to } \\
\text { elliptical and oval }\end{array}$ & $\begin{array}{l}\text { Elliptic to linear- } \\
\text { elliptic }\end{array}$ & Elliptical & Elliptical & Elliptical & $\begin{array}{l}\text { Narrow linear- } \\
\text { elliptical }\end{array}$ \\
\hline Axial area & $\begin{array}{l}\text { Tapers from the cen- } \\
\text { tral area, becoming } \\
\text { narrower towards } \\
\text { the ends }\end{array}$ & $\begin{array}{l}\text { Conforming with } \\
\text { the sternum }\end{array}$ & $\begin{array}{l}\text { Neither narrow } \\
\text { nor broad widen- } \\
\text { ing lanceolate to } \\
\text { the middle of the } \\
\text { valve }\end{array}$ & $\begin{array}{l}\text { Narrow-lanceolate, } \\
\text { more rarely linear, } \\
\text { differentiated } \\
\text { from a central } \\
\text { area }\end{array}$ & $\begin{array}{l}\text { Variable, never } \\
\text { narrow, but } \\
\text { more or less } \\
\text { widened to } \\
\text { lanceolate }\end{array}$ & $\begin{array}{l}\text { Slightly broad, } \\
\text { lanceolate } \\
\text { from the } \\
\text { middle of the } \\
\text { valve }\end{array}$ \\
\hline Central area & $\begin{array}{l}\text { More or less ex- } \\
\text { pressed, rounded to } \\
\text { asymmetrical, rarely } \\
\text { transversally elon- } \\
\text { gated, and bordered } \\
\text { on each margin by } \\
3 \text { shortened striae } \\
\text { and / or } 3 \text { isolated } \\
\text { areolae }\end{array}$ & $\begin{array}{l}\text { Very small to } \\
\text { absent, irregu- } \\
\text { larly delimited } \\
\text { by unequally } \\
\text { shortened striae }\end{array}$ & $\begin{array}{l}\text { Distinct central } \\
\text { area lacking }\end{array}$ & $\begin{array}{l}\text { Distinct trans- } \\
\text { versely-expanded } \\
\text { central area due to } \\
\text { some shortened } \\
\text { striae }\end{array}$ & $\begin{array}{l}\text { Distinct central } \\
\text { area lacking }\end{array}$ & $\begin{array}{l}\text { Distinct cen- } \\
\text { tral area lack- } \\
\text { ing }\end{array}$ \\
\hline $\begin{array}{l}\text { Valve length } \\
(\mu \mathrm{m})\end{array}$ & $9.1-10.5$ & $8-13$ & $7.5-10.5$ & (9) $10-12$ & (8?)9.0-9.5 & $7.0-8.7$ \\
\hline $\begin{array}{l}\text { Valve breadth } \\
(\mu \mathrm{m})\end{array}$ & $3.9-4.8$ & $3.5-4.5$ & $3.3-4.0$ & $3-5$ & $3.5-4.5$ & $3.0-4.5$ \\
\hline Striae & $\begin{array}{l}\text { Uniseriate, coarse, } \\
\text { almost parallel at the } \\
\text { valve centre, radial } \\
\text { at the valve ends, } \\
19-22 \text { in } 10 \mu \mathrm{m}\end{array}$ & $\begin{array}{l}\text { Uniseriate, } \\
\text { strongly radiate } \\
\text { throughout, } \\
\text { 18-22(-28) }\end{array}$ & $\begin{array}{l}\text { Uniseriate, mod- } \\
\text { erately radiate } \\
\text { throughout, } \\
18-20 \text { in } 10 \mu \mathrm{m}\end{array}$ & $\begin{array}{l}\text { Uniseriate, rela- } \\
\text { tively coarse, radi- } \\
\text { ate throughout, } \\
16-21 \text { in } 10 \mu \mathrm{m}\end{array}$ & $\begin{array}{l}\text { Biseriate, radi- } \\
\text { ate through- } \\
\text { out, } 20-24 \text { in } \\
10 \mu \mathrm{m}\end{array}$ & $\begin{array}{l}\text { Uniseri- } \\
\text { ate, radiate } \\
\text { throughout, } \\
22-24(-26)\end{array}$ \\
\hline Areolae & $20-30$ in $10 \mu \mathrm{m}$ & $40-50$ in $10 \mu \mathrm{m}$ & c.a. 40 in $10 \mu \mathrm{m}$ & 22 in $10 \mu \mathrm{m}$ & $70-80$ in $10 \mu \mathrm{m}$ & 50 in $10 \mu \mathrm{m}$ \\
\hline $\begin{array}{l}\text { Areolae per } \\
\text { stria }\end{array}$ & $1-3$ & $1-8$ & $2-6$ & $1-4$ & $\begin{array}{l}\text { 3-11 (in one } \\
\text { row stria) }\end{array}$ & $1-6$ \\
\hline Distribution & Holarctic & Holarctic & Sardinia, Italy & $\begin{array}{l}\text { Presumably cos- } \\
\text { mopolitan }\end{array}$ & Germany & Germany \\
\hline References & This study & $\begin{array}{l}\text { Mayama and } \\
\text { Kobayasi (1988), } \\
\text { Lange-Bertalot } \\
\text { (2001), Lange- } \\
\text { Bertalot et al. } \\
\text { (2017) }\end{array}$ & $\begin{array}{l}\text { Lange-Bertalot et } \\
\text { al. (2003) }\end{array}$ & $\begin{array}{l}\text { Lange-Bertalot et } \\
\text { al. (1996, 2017), } \\
\text { Lange-Bertalot } \\
\text { (2001), Kulikovs- } \\
\text { kiy (2006), Ku- } \\
\text { likovskiy et al. } \\
\text { (2016) }\end{array}$ & $\begin{array}{l}\text { Lange-Bertalot } \\
(2001), \text { Bar- } \\
\text { ragán et al. } \\
(2017)\end{array}$ & $\begin{array}{l}\text { Zimmermann } \\
\text { et al. (2014) }\end{array}$ \\
\hline
\end{tabular}

${ }^{\mathrm{a}}$ Determined from published data. 
per striae is high (3-6 in M. recondita vs. 1-3 in M. vietnamica sp. nov.).

Mayamaea terrestris resembles $M$. vietnamica sp. nov. in the shape of axial area, which expands towards the valve center. However, $M$. terrestris differs by lacking a central area, whereas in $M$. vietnamica sp. nov. the central area is well defined. The density of striae of $M$. terrestris is generally higher (22-24 [26] in $10 \mu \mathrm{m}$ vs. 19-22 in $10 \mu \mathrm{m}$ in $M$. vietnamica sp. nov.), as well as the density of areolae (50 in $10 \mu \mathrm{m}$ vs. 20 -30 in $10 \mu \mathrm{m}$ in M. vietnamica sp. nov.). The number of areolae in the striae in $M$. terrestris is also higher (1-6 against 1-3 in M. vietnamica sp. nov.).

\section{ACKNOWLEDGEMENTS}

Authors are grateful to the staff of the Centre of Electron Microscopy of the Papanin's Institute for Biology of Inland Waters, RAS, for technical assistance. Samples were collected during expeditions organized and permitted by the Joint Russian-Vietnam Tropical Centre, Ecolan 3.2 theme. The publication is based on research carried out with financial support by Russian Science Foundation (19-14-00320) for LM, sample investigation and (20-14-00211) for SEM within the framework of the state assignment (theme AAAA-A19-119041190086-6) for the finalization of the manuscript.

\section{REFERENCES}

Alverson, A. J., Jansen, R. K. \& Theriot, E. C. 2007. Bridging the Rubicon: phylogenetic analysis reveals repeated colonizations of marine and fresh waters by thalassiosiroid diatoms. Mol. Phylogenet. Evol. 45:193-210.

Arinushkina, E. V. 1970. Handbook for chemical analysis of soils. Publishing House of Moscow State University, Moscow, 487 pp. (in Russian).

Barragán, C., Ector, L. \& Wetzel, C. E. 2017. Mayamaea petersenii sp. nov., a new diatom from European aerial habitats and a brief appraisal on the morphological diversity of the genus. Algol. Stud. 153:71-87.

Blanc, L., Maury-Lechon, G. \& Pascal, J. -P. 2001. Structure, floristic composition and natural regeneration in the forests of Cat Tien National Park, Vietnam: an analysis of the successional trends. J. Biogeogr. 27:141-157.

Bruder, K. \& Medlin, L. K. 2008. Morphological and molecular investigations of naviculoid diatoms. II. Selected genera and families. Diatom Res. 23:283-329.

Darriba, D., Taboada, G. L., Doallo, R. \& Posada, D. 2012.
jModelTest 2: more models, new heuristics and highperformance computing. Nat. Methods 9:772.

Drummond, A. J. \& Rambaut, A. 2007. BEAST: Bayesian evolutionary analysis by sampling trees. BMC Evol. Biol. $7: 214$.

Foets, J., Wetzel, C. E., Teuling, A. J. \& Pfister, L. 2020. Temporal and spatial variability of terrestrial diatoms at the catchment scale: controls on communities. PeerJ 8:e8296.

Glushchenko, A., Genkal, S. I. \& Kulikovskiy, M. 2016. Aulacoseira konstantinovii sp. nov. and Aulacoseira krylovii sp. nov.: two new centric diatoms from South-east Asia. Diatom Res. 31:367-378.

Glushchenko, A., Kulikovskiy, M. \& Kociolek, J. P. $2017 a$. New and interesting species from the genus Luticola (Bacillariophyceae) in waterbodies of Southeastern Asia. Nova Hedwigia Beih. 146:157-173.

Glushchenko, A., Kulikovskiy, M. \& Kociolek, J. P. 2017b. New diatom species from the Gomphonema subtile-group in Southeast Asia. Phytotaxa 329:223-232.

Glushchenko, A., Kulikovskiy, M., Kuznetsova, I., Dorofeyuk, N. \& Kociolek, J. P. 2018. New species and combinations in the genus Eunotia Ehrenberg 1837 (Bacillariophyceae: Eunotiaceae) from waterbodies of Southeastern Asia. Nova Hedwigia Beih. 147:69-103.

Guillard, R. R. L. \& Lorenzen, C. J. 1972. Yellow-green algae with chlorophyllide $c$. J. Phycol. 8:10-14.

Guiry, M. D. \& Guiry, G. M. 2020. AlgaeBase. World-wide electronic publication, National University of Ireland, Galway. Available from: https://www.algaebase.org. Accessed Jun 12, 2020.

Hustedt, F. 1937. Systematische und ökologische Untersuchungen über die Diatomeen-Flora von Java, Bali und Sumatra nach dem Material der Deutschen Limnologischen Sunda-Expedition. "Tropische Binnengewässer, Band VII”. Arch. Hydrobiol. Suppl. 15:187-295.

Katoh, K. \& Toh, H. 2010. Parallelization of the MAFFT multiple sequence alignment program. Bioinformatics 26:1899-1900.

Kociolek, J. P., Blanco, S., Coste, M., Ector, L., Liu, Y., Karthick, B., Kulikovskiy, M., Lundholm, N., Ludwig, T., Potapova, M., Rimet, F., Sabbe, K., Sala, S., Sar, E., Taylor, J., Van de Vijver, B., Wetzel, C. E., Williams, D. M., Witkowski, A. \& Witkowski, J. 2020. DiatomBase. Available from: http:// www.diatombase.org. Accessed Jun 12, 2020.

Kolkwitz, R. \& Krieger, W. 1936. Zur Ökologie der Pflanzenwelt, insbesondere der Algen, des Vulkans Pangerango in West-Java. I. Allgemeines (von R. Kolkwitz). II. Die Algenflora des Pangerango (von W. Krieger). Ber. Deutsch. Bot. Ges. 54:65-91. 
Krasske, G. 1929. Beiträge zur Kenntnis der Diatomeenflora Sachsens. Bot. Arch. 27:348-380.

Kulikovskiy, M. S. 2006. Distribution and morphology of certain species from genera Mayamaea Lange-Bertalot and Fistulifera Lange-Bertalot (Bacillariophyta). Int. J. Algae 8:323-337.

Kulikovskiy, M. S., Glushchenko, A. M., Genkal, S. I. \& Kuznetsova, I. V. 2016. Identification book of diatoms from Russia. Filigran, Yaroslavl, 804 pp. (in Russian).

Kumar, S., Stecher, G. \& Tamura, K. 2016. MEGA7: Molecular Evolutionary Genetics Analysis version 7.0 for bigger datasets. Mol. Biol. Evol. 33:1870-1874.

Lange-Bertalot, H. 1997. Frankophila, Mayamaea and Fistulifera: three new genera of the class bacillariophyceae. Arch. Protist. 148:65-76.

Lange-Bertalot, H. 2001. Navicula sensu stricto, 10 genera separated from Navicula sensu lato, Frustulia. In LangeBertalot, H. (Ed.) Diatoms of Europe, Diatoms of the European Inland Waters and Comparable Habitats. Vol. 2. A.R.G. Gantner Verlag K.G., Ruggell, pp. 1-526.

Lange-Bertalot, H., Cavacini, P., Tagliaventi, N. \& Alfinito, S. 2003. Diatoms of Sardinia: rare and 76 new species in rock pools and other ephemeral waters. In Lange-Bertalot, H. (Ed.) Iconographia Diatomologica, Annotated Diatom Micrographs. Vol. 12. Koeltz Scientific Books, Königstein, pp. 1438.

Lange-Bertalot, H., Hofmann, G., Werum, M. \& Cantonati, M. 2017. Freshwater benthic diatoms of Central Europe: over 800 common species used in ecological assessment. English edition with updated taxonomy and added species. Koeltz Botanical Books, Schmitten-Oberreifenberg, $942 \mathrm{pp}$.

Lange-Bertalot, H., Külbs, K., Lauser, T., Nörpel-Schempp,
M. \& Willmann, M. 1996. Dokumentation und revision of the diatom taxa described by Georg Krasske. In Lange-Bertalot, H. (Ed.) Iconographia Diatomologica. Annotated Diatom Micrographs. Vol. 3. Koeltz Scientific Books, Königstein, pp. 1-358.

Mayama, S. \& Kobayasi, H. 1988. Morphological variations in Navicula atomus (Kütz.) Grun. In Round, F. E. (Ed.) Proc. Ninth Int. Diatom Symp., Biopress Ltd., Bristol-Koeltz Scientific Books, Koenigstein, pp. 427-435.

Noga, T., Kochman, N., Peszek, Ł., Stanek-Tarkowska, J. \& Pajączek, A. 2014. Diatoms (Bacillariophyceae) in rivers and streams and on cultivated soils of the Podkarpacie region in the years 2007-2011. J. Ecol. Eng. 15:6-25.

Ohtsuka, T. \& Fujita, Y. 2001. The diatom flora and its seasonal changes in a paddy field in Central Japan. Nova Hedwigia 73:97-128.

Reichardt, E. 2018. Die Diatomeen im Gebiet der Stadt Treuchtlingen. Bayerische Botanische Gesellschaft e.V., München, 1184 pp.

Ruck, E. C. \& Theriot, E. C. 2011. Origin and evolution of the canal raphe system in diatoms. Protist 162:723-737.

Schmidt, A. 1936. Atlas der Diatomaceen-kunde. Series VIII (Heft 101-102). O.R. Reisland, Leipzig, pls. 401-408.

Stamatakis, A., Hoover, P. \& Rougemont, J. 2008. A rapid bootstrap algorithm for the RAxML web servers. Syst. Biol. 57:758-771.

Vadjunina, A. F. \& Korchagina, Z. A. 1986. Methods of studying the physical properties of soils. Agropromisdat, Moscow, $416 \mathrm{pp}$.

Zimmermann, J., Abarca, N., Enk, N., Skibbe, O., Kusber, W. -H. \& Jahn, R. 2014. Taxonomic reference libraries for environmental barcoding: a best practice example from diatom research. PLoS ONE 9:e108793. 